\title{
Outdoor Air Pollution and Cardiovascular Diseases in Lebanon: A Case-Control Study
}

\author{
Zeina Nasser, ${ }^{1,2}$ Pascale Salameh, ${ }^{3}$ Habib Dakik, ${ }^{4}$ Elias Elias, ${ }^{5}$ \\ Linda Abou Abbas, ${ }^{1,2}$ and Alain Levêque ${ }^{6}$ \\ ${ }^{1}$ Clinical and Epidemiological Research Laboratory (LCER), Doctoral School of Sciences and Technology, Lebanese University, \\ Beirut 6573-14, Lebanon \\ ${ }^{2}$ School of Public Health, Free University of Brussels, Route de Lennik 808, CP 596, 1070 Brussels, Belgium \\ ${ }^{3}$ Clinical and Epidemiological Research Laboratory (LCER), Faculty of Pharmacy, Lebanese University, Beirut 6573-14, Lebanon \\ ${ }^{4}$ Division of Cardiology, Department of Internal Medicine, American University of Beirut, Riad El-Solh, Beirut 1107 2020, Lebanon \\ ${ }^{5}$ Division of Neurosurgery, Department of Surgery, American University of Beirut, Riad El-Solh, Beirut 1107 2020, Lebanon \\ ${ }^{6}$ Research Center in Epidemiology, Biostatistics and Clinical Research, School of Public Health, Free University of Brussels, \\ Route de Lennik 808, CP 596, 1070 Brussels, Belgium
}

Correspondence should be addressed to Zeina Nasser; znasser@ulb.ac.be

Received 31 August 2014; Revised 18 October 2014; Accepted 16 November 2014

Academic Editor: Sina Dobaradaran

Copyright (c) 2015 Zeina Nasser et al. This is an open access article distributed under the Creative Commons Attribution License, which permits unrestricted use, distribution, and reproduction in any medium, provided the original work is properly cited.

\begin{abstract}
Outdoor air pollution is increasingly considered as a serious threat for cardiovascular diseases (CVD). The aim of this study is to investigate the association between outdoor pollutants and cardiovascular diseases among adults in Lebanon and to examine the possible moderator effect of cigarette smoking status on this association. A multicenter case-control study was conducted between October 2011 and October 2012. Cases were hospitalized patients diagnosed with CVD by a cardiologist while the control group subjects were free of any cardiac diseases. Information on sociodemographic characteristics, tobacco consumption, self-rated global health, pollution exposure, and other risk factors was collected using a questionnaire. The results of the logistic regression revealed that living near busy highway (OR 5.04, 95\% CI (4.44-12.85), $P<0.001)$ and close to local diesel generator (OR 4.76, 95\% CI (2.0710.91), $P<0.001$ ) was significantly associated with CVD. The association between the CVD and exposure to outside pollutants differed by cigarette smoking status. A clear difference was noted between nonsmokers and current smokers OR 4.6, 95\% CI (1.1019.25) and OR 10.11, 95\% CI (7.33-20.23), respectively. Forthcoming studies are needed to clarify the potential link between outdoor air pollution and cardiovascular diseases in Lebanon. Public health interventions must be implemented to reduce air pollution and to improve air quality.
\end{abstract}

\section{Introduction}

Outdoor air pollution, composed of complex mixtures including gases (e.g., carbon monoxide (CO), nitrogen dioxide $\left(\mathrm{NO}_{2}\right)$, ozone $\left(\mathrm{O}_{3}\right)$, sulfur dioxide $\left(\mathrm{SO}_{2}\right)$, and particulate matter $(\mathrm{PM})$ ), is increasingly considered a new threat to the cardiac system [1-4]. It is manifested by endothelial dysfunction, hypertension, and increased thrombogenic and inflammatory state [5]. Researchers noticed as early as the 1920s and 1930s the impact of air pollution on human health: high rates of death events occurred in London and Belgium after stagnant weather conditions caused by a sharp increase in the concentration of air pollutants for many days [6]. Literature uncovered the fact that even shy amounts of exposure to pollutants can have deleterious effects on the health in terms of morbidity and mortality [2,7]. Several epidemiological studies on air pollution and cardiovascular diseases (CVD) are from developed countries [2, 8, 9]; unfortunately, this has been less investigated in developing countries, although they have similar or higher pollutant concentrations [10].

Motor vehicle emissions are recognized as a major source of outdoor air pollution [11]. Pollutants include organic compounds, carbon monoxide, nitrogen-sulfur oxides, unburned hydrocarbons, and PM [12]. Recently, traffic related air 
pollution is considered a risk factor for myocardial infarction (MI) [13]. Living within vicinity of highways, up to a radius of 100 meters, was considered as another risk of acute myocardial events [14]. Moreover, certain types of professions are at higher risk for cardiac events, such as taxi or bus drivers [13], waste incinerator workers [15], smelters operatives [16], or chimney sweeps $[17,18]$. On the other hand, road vehicles were identified as a major contributing factor to air pollution emissions in the Middle East region [19]. Lebanon, a small growing nation, endured fifteen years of civil war leaving the infrastructure in a wreck, leading to a constant long shortage hours of electricity and forcing the public to install their own local diesel generators. Moreover, public transportation is mostly nonexistent and old vehicles with poor maintenance are widely spread [20]. In fact, a recent study conducted by Saliba et al. which measured PMs $\left(\mathrm{PM}_{10}\right.$ and $\mathrm{PM}_{2.5}: \mathrm{PM}$ with aerodynamic diameters less than 10 and $2.5 \mu \mathrm{m}$, resp.) concentrations in three sites in the capital Beirut (postwar 2006 construction activities, urban area, and populated area) revealed that Lebanon suffered from high PM levels [21] exceeding the World Health Organization (WHO) recommended values $\left(\mathrm{PM}_{10} 20 \mu \mathrm{g} / \mathrm{m}^{3} ; \mathrm{PM}_{2.5} 10 \mu \mathrm{g} / \mathrm{m}^{3}\right)$ [22].

So far no study has specifically assessed the association between outdoor air pollution and cardiovascular diseases in our country. The specific aim of our paper is to investigate this association among adults in Lebanon and to examine the possible moderator effect of cigarette smoking.

\section{Methods}

2.1. Study Design and Population. It is a multicenter casecontrol study, conducted between October 2011 and October 2012, in six hospitals in Lebanon, comparing CVD cases to a control group. Cases were defined as patients aged 40 years or above, hospitalized for cardiovascular disease, diagnosed with ST/non-ST elevation, myocardial infarction, stable/unstable angina, or heart failure, confirmed by a cardiologist based on their clinical presentation and laboratory exams [23]. The control group consisted of any subject aged 40 years or above admitted to the same hospitals for reasons excluding diabetes, hypertension, dyslipidemia, respiratory problems, or cardiovascular diseases. All participants signed an informed consent before enrolment in our study. Only 3 cases and 7 controls refused to take part in our research.

2.2. Data Collection. The Institutional Review Board (IRB) of our university waived the need for an official approval due to the observational nature of our study. A face to face interview was completed by three independent investigators trained in a standardized manner filling out an anonymous questionnaire. Charting was performed for the sake of data completion. Participant's anonymity and confidentiality were respected. Variables included a spectrum of sociodemographic characteristics such as age, gender, urban or rural residence, marital status (single, married, divorced, or widowed), education (illiteracy or primary, complementary, secondary, and university levels), and income-per-familymember (IPFM). IPFM, a measure defined as the household monthly income of a family divided by number of its members, was then categorized into quartiles (low, medium low, medium high, and highest). Health and behavior habits questions were included. For instance, cases and controls were asked to evaluate their health condition: "How would you describe your current health status" on a 10-point scale. Smoking status was also assessed for cigarette and water pipe smoking separately. Due to the small number of previous cigarette smokers, this subgroup was combined with current smokers. Passive smoking at home and at work was also weighed. On the subject of pollution, the traffic exposure indicator was assessed by the following question: "Are you living near a busy highway (<100 meters, >100 meters)?" The diesel emission exposure indicator was evaluated by the following question: "Are you living close to local diesel generator"? Traditional cardiovascular risk factors (CVRFs) were also collected from the hospital charts: hypertension, triglyceride, HDL (high density lipoprotein concentration), LDL (low density lipoprotein concentration), family history of cardiovascular disease (CVD), and obesity according to Body Mass Index scale (BMI) "normal weight" (BMI $18.5-24.9 \mathrm{~kg} / \mathrm{m}^{2}$ ), "overweight" (BMI $25.0-29.9 \mathrm{~kg} / \mathrm{m}^{2}$ ), and "obese" (BMI $\left.\geq 30 \mathrm{~kg} / \mathrm{m}^{2}\right)[24]$.

2.3. Sample Size Calculation. Sample size calculation was done with a type I error of $5 \%$ and a study power of $80 \%$. In the absence of baseline data, the exposure of healthy Lebanese residents to pollution was considered to be equal to $50 \%$. The minimal sample size necessary to show a twofold increase in risk of cardiovascular diseases consisted of 330 subjects, divided into 111 cases and 222 controls. In the present study the simple size was 340 divided into 121 cases and 219 controls.

2.4. Statistical Analysis. The data entry was performed by independent laypersons that were unaware of the objectives of the study. Data cleaning was carried out by the researchers. Statistical analysis was performed using SPSS IBM version 20.0. Means with their $95 \%$ confidence intervals, medians with their interquartile ratio, and percentages were used to describe continuous and categorical variables. Statistical bivariate analysis was performed. The Pearson chi-square $\left(\chi^{2}\right)$ test was used for categorical variables. Student's $t$-test and Mann-Whitney $U$ test were run for the continuous variables to compare their means. A $P$ value $<0.05$ was considered statistically significant. A multivariate analysis using logistic regression was carried out with CVD as the dependent variable. Adjusted odds ratios and their 95\% confidence intervals were reported. The final logistic regression model was reached after ensuring the adequacy of our data using the Hosmer-Lemeshow test. Furthermore, due to the presumed relationship of cigarette smoking with both CVD [25] and exposure to outdoor air pollution [26], the interaction effect of this variable was tested $(P$ value $<0.001)$. The regression model was stratified according to cigarette smoking status.

\section{Results}

3.1. Characteristics of the Study Sample. The baseline characteristics of our participants are described in Table 1. A total of 340 individuals were enrolled in the study: 219 (64.4\%) 
TABLE 1: Baseline characteristics of the participants.

\begin{tabular}{|c|c|c|c|}
\hline Characteristics & $\begin{array}{c}\text { Controls } \\
n=219(\%)\end{array}$ & $\begin{array}{c}\text { Cases } \\
n=121(\%)\end{array}$ & $P$ value \\
\hline Age & & & $0.007^{*}$ \\
\hline $40-44$ & $43(19.7)$ & $7(5.9)$ & \\
\hline $45-49$ & $25(11.5)$ & $11(9.2)$ & \\
\hline $50-54$ & $16(7.3)$ & $18(15.1)$ & \\
\hline $55-59$ & $16(7.3)$ & $10(8.4)$ & \\
\hline $60-64$ & $28(12.8)$ & $20(16.8)$ & \\
\hline$\geq 65$ & $90(41.3)$ & $53(44.5)$ & \\
\hline Gender & & & 0.902 \\
\hline Males & $116(53.0)$ & $63(52.5)$ & \\
\hline Females & $103(47.0)$ & $58(47.5)$ & \\
\hline Marital status & & & $<0.001^{*}$ \\
\hline Single & $36(16.4)$ & $1(0.8)$ & \\
\hline Married & $157(71.7)$ & $104(86.7)$ & \\
\hline Divorced or widow & $26(11.9)$ & $15(12.5)$ & \\
\hline Education & & & $0.025^{*}$ \\
\hline Illiteracy & $23(10.5)$ & $11(9.7)$ & \\
\hline Primary or less & $82(37.4)$ & $60(53.1)$ & \\
\hline Complementary or less & $48(21.9)$ & $25(22.1)$ & \\
\hline Secondary or less & $37(16.9)$ & $10(8.8)$ & \\
\hline University degree & $27(13.2)$ & $7(6.2)$ & \\
\hline Residency & & & $0.033^{*}$ \\
\hline Rural & $117(53.4)$ & $50(41.3)$ & \\
\hline Urban & $102(46.6)$ & $71(58.7)$ & \\
\hline Income-per-family-member & & & 0.221 \\
\hline Low & $58(27.0)$ & $35(30.2)$ & \\
\hline Med. low & $27(12.6)$ & $23(19.8)$ & \\
\hline Med. high & $76(35.3)$ & $35(30.2)$ & \\
\hline Highest & $54(25.1)$ & $23(19.8)$ & \\
\hline $\mathrm{BMI}^{\mathrm{a}}$ & & & $0.004^{*}$ \\
\hline Normal (BMI 18.5-24.9) & $71(32.4)$ & $22(19.0)$ & \\
\hline Overweight (BMI 25-29.9) & $102(46.4)$ & $53(45.7)$ & \\
\hline Obese (BMI $\geq 30)$ & $46(21.0)$ & $41(35.3)$ & \\
\hline Family history of $\mathrm{CVD}^{\mathrm{b}}$ & & & $0.012^{*}$ \\
\hline No & $143(65.9)$ & $62(51.7)$ & \\
\hline Yes & $74(34.1)$ & $58(48.3)$ & \\
\hline $\begin{array}{l}\text { Triglycerides mg/dL } \\
(\text { mean } \pm \mathrm{SD})^{\mathrm{c}}\end{array}$ & $146.5 \pm 43.6$ & $202.2 \pm 67.0$ & $<0.001^{*}$ \\
\hline $\mathrm{LDL} \mathrm{mg} / \mathrm{dL}^{\mathrm{d}}(\text { mean } \pm \mathrm{SD})^{\mathrm{c}}$ & $86.4 \pm 46.3$ & $128.9 \pm 38.3$ & $<0.001^{*}$ \\
\hline $\mathrm{HDL} \mathrm{mg} / \mathrm{dL}^{\mathrm{e}}(\text { mean } \pm \mathrm{SD})^{\mathrm{c}}$ & $51.7 \pm 15.6$ & $43.3 \pm 14.1$ & $<0.001^{*}$ \\
\hline $\operatorname{SBP} \operatorname{mmHg}^{\mathrm{f}}(\text { mean } \pm \mathrm{SD})^{\mathrm{c}}$ & $122.5 \pm 15.04$ & $129.9 \pm 19.1$ & $<0.001^{*}$ \\
\hline $\begin{array}{l}\text { Self-related global health } \\
(\text { mean } \pm S D)^{c}\end{array}$ & $8.3 \pm 0.6$ & $5.9 \pm 1.4$ & $<0.001^{*}$ \\
\hline
\end{tabular}

${ }^{\mathrm{a}} \mathrm{BMI}$, body mass index; ${ }^{\mathrm{b}}$ cardiovascular disease; ${ }^{\mathrm{c}}$ mean \pm standard deviation; ${ }^{\mathrm{d}} \mathrm{LDL}$, low density lipoprotein; ${ }^{\mathrm{e}} \mathrm{HDL}$, high density lipoprotein; ${ }^{\mathrm{f}} \mathrm{SBP}$, systolic blood pressure; ${ }^{*} P$ value $<0.05$ statistically significant.

controls and 121 (35.6\%) cases. Living in urban areas, older age, and lower educational level were more common in
TABLE 2: Subject's exposure to active and passive smoking and CVD.

\begin{tabular}{lccc}
\hline Variable & $\begin{array}{c}\text { Controls } \\
n=219(\%)\end{array}$ & $\begin{array}{c}\text { Cases } \\
n=121(\%)\end{array}$ & OR (95\% CI) \\
\hline $\begin{array}{l}\text { Cigarette smoking } \\
\text { status }\end{array}$ & & & \\
$\quad$ Nonsmokers & $137(63.1)$ & $57(47.1)$ & \\
$\quad$ Current smokers & $80(36.9)$ & $64(52.9)$ & $1.92(1.22-3.01)$ \\
$\begin{array}{l}\text { Passive cigarette } \\
\text { smoking at home }\end{array}$ & & & \\
$\quad$ No & $106(51.2)$ & $37(30.8)$ & \\
$\quad$ Yes & $101(48.8)$ & $83(69.2)$ & $2.35(1.46-3.78)$ \\
$\begin{array}{l}\text { Passive cigarette } \\
\text { smoking at work }\end{array}$ & & & \\
$\quad$ No & $21(32.3)$ & $15(33.3)$ & \\
$\quad$ Yes & $44(67.7)$ & $30(66.7)$ & $0.95(0.42-2.14)$ \\
Water pipe & & & \\
smoking status & & & \\
$\quad$ Nonsmoker & $170(78.0)$ & $100(82.6)$ & \\
$\quad$ Current smoker & $48(22.0)$ & $21(17.4)$ & $0.74(0.42-1.31)$ \\
\hline OR: odds ratio; CI: confidence interval. & &
\end{tabular}

OR: odds ratio; CI: confidence interval.

cases than controls. Additionally, the BMI and the means of the risk factors (hypertension, triglycerides, and LDL) were significantly higher among cases.

3.2. Association between Smoking and CVD. The results of the bivariate analysis for smoking exposure (active or passive) and cardiovascular diseases are presented in Table 2. Current cigarette smokers had significantly higher risk of CVD than nonsmokers with an odds ratio (OR) of 1.92 and a $95 \%$ confidence interval (CI) between 1.22 and 3.01. A positive association was also found with passive smoking at home, OR 2.35 and 95\% CI (1.46-3.78). Regarding water pipe and passive cigarette smoking at work, no significant association was pronounced.

3.3. Association between Outdoor Pollution, Cumulative Exposure, and CVD. All types of outdoor air pollution exposure were significantly associated with CVD. Furthermore, we noted an evidence of increased risk of CVD with long duration of living near a busy highway $(P=0.001$, test for trend) and with extended duration of living close to local diesel generator $(P<0.001$, test for trend) (Table 3$)$.

3.4. Multivariate Analysis. All significant variables in bivariate analysis were included in the multivariate logistic regression. The model was suitable and Hosmer-Lemeshow test was adequate. Living near busy highway OR 5.04 and 95\% CI (4.44-12.85) and living close to local diesel generator OR 4.76 and $95 \%$ CI (2.07-10.91) remained significantly associated with CVD after adjusting for HDL, LDL, triglyceride, SBP, and cigarette smoking status (Table 4). In an attempt to assess the dose-effect relationship, we also conducted another multivariate analysis where we treated the duration of living near busy highway and living close to local diesel generator as independent continuous variables instead of a dichotomous 
TABLE 3: Exposure to outdoor air pollution and CVD.

\begin{tabular}{|c|c|c|c|}
\hline Variable & $\begin{array}{c}\text { Controls } \\
n=219(\%)\end{array}$ & $\begin{array}{c}\text { Cases } \\
n=121(\%)\end{array}$ & OR (95\% CI) \\
\hline \multicolumn{4}{|l|}{ Highway proximity $^{\mathrm{a}}$} \\
\hline$>100 \mathrm{~m}$ & $128(58.4)$ & $47(38.8)$ & \\
\hline$<100 \mathrm{~m}$ & $91(41.6)$ & $74(61.2)$ & $2.21(1.40-3.48)$ \\
\hline \multicolumn{4}{|l|}{$\begin{array}{l}\text { Living duration near } \\
\text { highway }^{\mathrm{b}}\end{array}$} \\
\hline Never & $143(65.3)$ & $53(4.38)$ & 1.00 \\
\hline 1 to 14 years & $18(8.2)$ & $11(9.1)$ & $1.14(0.73-3.72)$ \\
\hline 15 to 30 years & $26(11.9)$ & $28(23.1)$ & $1.51(1.12-4.28)$ \\
\hline 31 years or more & $32(14.6)$ & $29(24.0)$ & $2.28(1.62-5.77)$ \\
\hline \multicolumn{4}{|l|}{$\begin{array}{l}\text { Local diesel generator } \\
\text { proximity }^{c}\end{array}$} \\
\hline No & $166(75.8)$ & $61(50.4)$ & \\
\hline Yes & $53(24.2)$ & $60(49.6)$ & $3.08(1.92-4.93)$ \\
\hline \multicolumn{4}{|c|}{$\begin{array}{l}\text { Living duration near } \\
\text { local diesel generator }^{\mathrm{d}}\end{array}$} \\
\hline Never & $166(75.8)$ & $61(50.4)$ & 1.00 \\
\hline 1 to 10 years & $28(12.8)$ & $29(24.0)$ & $2.81(1.55-5.11)$ \\
\hline 11 years and more & $25(11.4)$ & $31(25.6)$ & $3.37(1.84-6.16)$ \\
\hline
\end{tabular}

${ }^{a}$ Are you living near a busy highway?; ${ }^{b}$ duration of living near a busy highway; ${ }^{\mathrm{c}}$ Are you living close to local diesel generator?; ${ }^{\mathrm{d}}$ duration of living close to local diesel generator; OR: odds ratio; CI: confidence interval.

TABLE 4: Adjusted odds ratios with their 95\% confidence intervals from the logistic regression of CVD among cases and control.

\begin{tabular}{lccc}
\hline Global model & OR $^{\mathrm{a}}$ & $95 \%$ CI & $P$ value \\
\hline $\begin{array}{l}\text { Living near a busy highway } \\
\quad<100 \mathrm{~m}\end{array}$ & 1.0 & & $<0.001^{*}$ \\
$\quad>100 \mathrm{~m}$ & 5.04 & $4.44-12.85$ & \\
$\begin{array}{l}\text { Living close to local diesel generator } \\
\begin{array}{l}\text { Dose-effect relationship } \\
\quad\end{array}\end{array}$ & 4.76 & $2.07-10.91$ & $<0.001^{*}$ \\
$\quad \begin{array}{l}\text { Duration of living near a busy } \\
\text { highway }\end{array}$ & 1.05 & $1.02-1.07$ & $0.016^{*}$ \\
$\begin{array}{l}\text { Duration of living close to local } \\
\text { diesel generator }\end{array}$ & 1.38 & $1.10-1.78$ & $0.014^{*}$ \\
\hline
\end{tabular}

Global model: adjusted for triglyceride, HDL, LDL, SBP, and cigarette smoker status. $\mathrm{OR}^{\mathrm{a}}$ : adjusted odds ratio; $\mathrm{CI}$ : confidence interval; ${ }^{*} P$ value $<0.05$ statistically significant. ${ }^{* *}$ Dose-effect relationship: adjusted for triglyceride, HDL, LDL, SBD, and cigarette smoker status. OR ${ }^{a}$ : adjusted odds ratio; CI: confidence interval; ${ }^{*} P$ value $<0.05$ statistically significant.

set. The association between cumulative exposure and CVD remained significant. We observed an increased occurrence of cardiovascular diseases with long exposure to outdoor pollutants. The OR was 1.05, 95\% CI (1.02-1.07), and $P=0.016$ for duration of living near busy highway and 1.38, 95\% CI (1.10-1.78), and $P=0.014$ for duration of living close to a local diesel generator (Table 4). An interaction effect of cigarette smoking was noticed on the association between CVD and living near busy highway ( $P$ for interaction: $<0.001)$. Our results revealed a clear difference between nonsmokers and current smokers OR 4.6 and 95\% CI (1.10-19.25) and OR
10.11 and 95\% CI (7.33-20.23), respectively. However, no interaction was found while examining any possible effect of cigarette smoking status on the association between living close to diesel generator and CVD ( $P$ for interaction: 0.24 ) (Table 5).

\section{Discussion}

This is, to our knowledge, the first case-control study conducted to evaluate the association between outdoor air pollution and CVD among adults in Lebanon and to examine the potential moderator effect of cigarette smoking status on this association.

We found that CVD was associated with outdoor air pollution such as living near busy highway and living close to a local diesel generator. In accordance with our findings, several epidemiological studies showed that traffic particles are associated with cardiovascular diseases. A recent casecontrol study correlated long traffic exposure measured by $\mathrm{PM}_{2.5}$ and $\mathrm{NO}_{2}$ levels with an increase in acute myocardial infarction events [27]. Even more, evidence is emerging that long-term exposure to air pollution or traffic indicators is associated with measures of subclinical atherosclerosis [28, 29]. On the other hand, one of the risk factors proposed by other papers was the vicinity of the subjects' housing to major highways [30]. A five-year cohort study found that living close to traffic road was associated with mortality from cardiovascular incidence [31]. Our results also showed that cigarette smoking has a modification effect on the association, hence the importance of stratification by smokers status. The modifier effect of cigarette smoking status was evident in a study conducted by Pope III et al. [4]. Upon stratifying by cigarette smoking, we noticed that the risk of CVD of subjects exposed to outdoor air pollution is higher for current smokers compared to nonsmokers. A recent study evaluated the cellular toxicity of PM in the capital Beirut (near busy highways and urban background sites) using rat macrophage cells. It showed that PM stimulated the formation of reactive oxygen species (ROS) and triggered oxidative stress in these cells [32]. Numerous studies support evidence of a biological mechanism relating the air pollution toxins to changes in the cardiac system. In fact, PM exposure induced formation of atherosclerotic lesions in a study using rabbits as experimental specimens [33]. Regarding humans, a controlled exposure experiment to PM triggered both an acute and a long lasting inflammatory response $[34,35]$. Toxic pollutants activate prothrombotic pathway and fibrinogen formation [28, 34], accelerating the formation of atherosclerosis, intensifying the risk of myocardial infarctions $[2,36]$. In other studies, a predictor of cardiovascular events was assessed by elevation of $\mathrm{C}$ reactive protein level (a marker of myocardial infarction) upon exposure to PM [37, 38].

Consistent with other studies, dose-effect relationship, temporal relationship, and biological plausibility are strength points in our paper. Our study has however some limitations. The possibility of recall bias might be entertained due to the retrospective nature of our investigation. Cardiologist recruiting subjects were also unaware of their exposure status; this may decrease selection bias, which however cannot 
TABLE 5: Adjusted odds ratios with their 95\% confidence intervals from the logistic regression of CVD among cases and control stratified by cigarette smoking status.

\begin{tabular}{|c|c|c|c|c|c|c|}
\hline \multirow{3}{*}{ Exposure type } & \multicolumn{6}{|c|}{ Cigarette smoking } \\
\hline & \multicolumn{3}{|c|}{ Nonsmokers } & \multicolumn{3}{|c|}{ Current smokers } \\
\hline & $\mathrm{OR}^{\mathrm{a}}$ & $95 \% \mathrm{CI}$ & $P$ value & $\mathrm{OR}^{\mathrm{a}}$ & $95 \% \mathrm{CI}$ & $P$ value \\
\hline Living near a busy highway & & & $0.030^{*}$ & & & $<0.001^{*}$ \\
\hline$<100 \mathrm{~m}$ & 1.0 & & & 1.0 & & \\
\hline$>100 \mathrm{~m}$ & 4.60 & $1.10-19.25$ & & 10.11 & $7.33-20.23$ & \\
\hline Living close to local diesel generator & 4.97 & $1.64-15.08$ & $0.005^{*}$ & 5.02 & $1.52-11.93$ & $0.004^{*}$ \\
\hline
\end{tabular}

Adjusted for triglyceride, $\mathrm{HDL}, \mathrm{LDL}$, and SBP; $\mathrm{OR}^{\mathrm{a}}$ : adjusted odds ratio; CI: confidence interval. ${ }^{*} P$ value $<0.05$ statistically significant.

be excluded. There was also a possibility of interview bias since the questionnaires were filled by three independent investigators. Although we carried out a multivariate analysis to remove the confounding effects of several factors, there is still a possibility of residual confounding due to unmeasured factors. A further limitation in this study is that there are no national strategies in Lebanon aiming to assess the risk of air quality on the citizen's health. In addition, there are no actions in Lebanon to implement the indoor and outdoor Clean Air Act to control air pollution. Assessment of air pollution was based on self-reported information from both groups (cases and controls). The lack of air monitoring stations in Lebanon can represent inaccurate outdoor air pollutant levels. Therefore, the vicinity of sources was used as proxy instead of the quantitative air pollutant measurements. Studies conducted on measurement of air pollution concentrations are scarce and restricted only to the capital Beirut. Our paper should motivate the Lebanese government to establish permanent stations for monitoring general air quality across all the Lebanese territories.

In conclusion, we found that outdoor air pollution exposure, such as living near local diesel generator or a busy highway, was associated with CVD. These results were also confirmed by dose-effect and temporal relationship. Further studies should attempt to link air pollutants with the appropriate cardiac events (MI, heart rate variability, heart failure, unstable angina, etc.). In terms of public health practice, implementation of policy options to reduce traffic related air pollution and to develop a strategy to improve air quality is a necessity.

\section{Conflict of Interests}

The author and coauthors have nothing to disclose in terms of financial grants or funding and have no competing interests regarding the submitted paper.

\section{References}

[1] C. A. Pope III, R. T. Burnett, M. J. Thun et al., "Lung cancer, cardiopulmonary mortality, and long-term exposure to fine particulate air pollution," JAMA, vol. 287, no. 9, pp. 1132-1141, 2002.

[2] R. D. Brook, B. Franklin, W. Cascio et al., "Air pollution and cardiovascular disease: a statement for healthcare professionals from the expert panel on population and prevention science of the American Heart Association," Circulation, vol. 109, no. 21, pp. 2655-2671, 2004.

[3] C. A. Pope III and D. W. Dockery, "Health effects of fine particulate air pollution: lines that connect," Journal of the Air and Waste Management Association, vol. 56, no. 6, pp. 709-742, 2006.

[4] C. A. Pope III, R. T. Burnett, G. D. Thurston et al., "Cardiovascular mortality and long-term exposure to particulate air pollution: epidemiological evidence of general pathophysiological pathways of disease," Circulation, vol. 109, no. 1, pp. 71-77, 2004.

[5] R. D. Brook, S. Rajagopalan, C. A. Pope et al., "Particulate matter air pollution and cardiovascular disease: an update to the scientific statement from the American Heart Association," Circulation, vol. 121, no. 21, pp. 2331-2378, 2010.

[6] B. Nemery, P. H. M. Hoet, and A. Nemmar, "The Meuse Valley fog of 1930: an air pollution disaster," The Lancet, vol. 357, no. 9257, pp. 704-708, 2001.

[7] G. H. Tofler and J. E. Muller, "Triggering of acute cardiovascular disease and potential preventive strategies," Circulation, vol. 114, no. 17, pp. 1863-1872, 2006.

[8] C. A. Pope III, M. L. Hansen, R. W. Long et al., "Ambient particulate air pollution, heart rate variability, and blood markers of inflammation in a panel of elderly subjects," Environmental Health Perspectives, vol. 112, no. 3, pp. 339-345, 2004.

[9] T.-C. Su, S.-Y. Chen, and C.-C. Chan, "Progress of ambient air pollution and cardiovascular disease research in Asia," Progress in Cardiovascular Diseases, vol. 53, no. 5, pp. 369-378, 2011.

[10] D. G. Fullerton, N. Bruce, and S. B. Gordon, "Indoor air pollution from biomass fuel smoke is a major health concern in the developing world," Transactions of the Royal Society of Tropical Medicine and Hygiene, vol. 102, no. 9, pp. 843-851, 2008.

[11] D. Brugge, J. L. Durant, and C. Rioux, "Near-highway pollutants in motor vehicle exhaust: a review of epidemiologic evidence of cardiac and pulmonary health risks," Environmental Health, vol. 6, article 23, 2007.

[12] M. Habermann and N. Gouveia, "Motor vehicle traffic and cardiovascular mortality in male adults," Revista de Saude Publica, vol. 46, no. 1, pp. 26-33, 2012.

[13] F. B. Stern, W. E. Halperin, R. W. Hornung, V. L. Ringenburg, and C. S. McCammon, "Heart disease mortality among bridge and tunnel officers exposed to carbon monoxide," The American Journal of Epidemiology, vol. 128, no. 6, pp. 1276-1288, 1988.

[14] C. Tonne, S. Melly, M. Mittleman, B. Coull, R. Goldberg, and J. Schwartz, "A case-control analysis of exposure to traffic and acute myocardial infarction," Environmental Health Perspectives, vol. 115, no. 1, pp. 53-57, 2007. 
[15] P. Gustavsson, "Mortality among workers at a municipal waste incinerator," The American Journal of Industrial Medicine, vol. 15, no. 3, pp. 245-253, 1989.

[16] G. P. Theriault, C. G. Tremblay, and B. G. Armstrong, "Risk of ischemic heart disease among primary aluminum production workers," The American Journal of Industrial Medicine, vol. 13, no. 6, pp. 659-666, 1988.

[17] E. S. Hansen, "Mortality from cancer and ischemic heart disease in Danish chimney sweeps: a five-year follow-up," American Journal of Epidemiology, vol. 117, no. 2, pp. 160-164, 1983.

[18] B. A. Evanoff, P. Gustavsson, and C. Hogstedt, "Mortality and incidence of cancer in a cohort of Swedish chimney sweeps: an extended follow up study," British Journal of Industrial Medicine, vol. 50, no. 5, pp. 450-459, 1993.

[19] A. Waked and C. Afif, "Emissions of air pollutants from road transport in Lebanon and other countries in the Middle East region," Atmospheric Environment, vol. 61, pp. 446-452, 2012.

[20] R. Baalbaki, K. Al-Assaad, C.-J. Mehanna, N. A. Saliba, M. Katurji, and M. Roumié, "Road versus roadside particle size distribution in a hot Mediterranean summe-estimation of fleet emission factors," Journal of the Air and Waste Management Association, vol. 63, no. 3, pp. 327-335, 2013.

[21] N. A. Saliba, F. El Jam, G. El Tayar, W. Obeid, and M. Roumie, "Origin and variability of particulate matter (PM10 and PM2.5) mass concentrations over an Eastern Mediterranean city," Atmospheric Research, vol. 97, no. 1-2, pp. 106-114, 2010.

[22] WHO, Air Quality Guidelines for Particulate Matter, Ozone, Nitrogen Dioxide and Sulfur Dioxide: Global Update, World Health Organization, Lyon, France, 2005.

[23] "Guidelines for the management of adults with hospitalacquired, ventilator-associated, and healthcare-associated pneumonia," American Journal of Respiratory and Critical Care Medicine, vol. 171, no. 4, pp. 388-416, 2005.

[24] Obesity: Preventing and Managing the Global Epidemic. Report of a WHO Consultation, vol. 894 of World Health Organization Technical Report Series, WHO, Geneva, Switzerland, 2000.

[25] I. S. Ockene and N. H. Miller, "Cigarette smoking, cardiovascular disease, and stroke: a statement for healthcare professionals from the American Heart Association. American Heart Association Task Force on Risk Reduction," Circulation, vol. 96, no. 9, pp. 3243-3247, 1997.

[26] R. J. Shephard, "Cigarette smoking and reactions to air pollutants," Canadian Medical Association Journal, vol. 118, no. 4, pp. 379-392, 1978.

[27] C. Tonne, J. Yanosky, A. Gryparis et al., "Traffic particles and occurrence of acute myocardial infarction: a case-control analysis," Occupational and Environmental Medicine, vol. 66, no. 12, pp. 797-804, 2009.

[28] N. Künzli, M. Jerrett, W. J. Mack et al., "Ambient air pollution and atherosclerosis in Los Angeles," Environmental Health Perspectives, vol. 113, no. 2, pp. 201-206, 2005.

[29] B. Hoffmann, S. Moebus, S. Möhlenkamp et al., "Residential exposure to traffic is associated with coronary atherosclerosis," Circulation, vol. 116, no. 5, pp. 489-496, 2007.

[30] B. Hoffmann, S. Moebus, A. Stang et al., "Residence close to high traffic and prevalence of coronary heart disease," European Heart Journal, vol. 27, no. 22, pp. 2696-2702, 2006.

[31] W. Q. Gan, L. Tamburic, H. W. Davies, P. A. Demers, M. Koehoorn, and M. Brauer, "Changes in residential proximity to road traffic and the risk of death from coronary heart disease," Epidemiology, vol. 21, no. 5, pp. 642-649, 2010.
[32] N. Daher, N. A. Saliba, A. L. Shihadeh et al., "Oxidative potential and chemical speciation of size-resolved particulate matter (PM) at near-freeway and urban background sites in the greater Beirut area," Science of the Total Environment, vol. 470-471, pp. 417-426, 2014.

[33] T. Suwa, J. Hogg, K. Quinlan, A. Ohgami, R. Vincent, and S. F. Van Eeden, "Particulate air pollution induces progression of atherosclerosis," Journal of the American College of Cardiology, vol. 39, no. 6, pp. 935-942, 2002.

[34] A. J. Ghio, C. Kim, and R. B. Devlin, "Concentrated ambient air particles induce mild pulmonary inflammation in healthy human volunteers," The American Journal of Respiratory and Critical Care Medicine, vol. 162, no. 3, part 1, pp. 981-988, 2000.

[35] S. Salvi, A. Blomberg, B. Rudell et al., "Acute inflammatory responses in the airways and peripheral blood after short-term exposure to diesel exhaust in healthy human volunteers," The American Journal of Respiratory and Critical Care Medicine, vol. 159, no. 3, pp. 702-709, 1999.

[36] A. V. Diez Roux, A. H. Auchincloss, T. G. Franklin et al., "Longterm exposure to ambient particulate matter and prevalence of subclinical atherosclerosis in the multi-ethnic study of atherosclerosis," American Journal of Epidemiology, vol. 167, no. 6, pp. 667-675, 2008.

[37] A. Peters, M. Fröhlich, A. Döring et al., "Particulate air pollution is associated with an acute phase response in men: results from the MONICA-Augsburg study," European Heart Journal, vol. 22, no. 14, pp. 1198-1204, 2001.

[38] P. M. Ridker, N. Rifai, L. Rose, J. E. Buring, and N. R. Cook, "Comparison of C-reactive protein and low-density lipoprotein cholesterol levels in the prediction of first cardiovascular events," The New England Journal of Medicine, vol. 347, no. 20, pp. 1557-1565, 2002. 


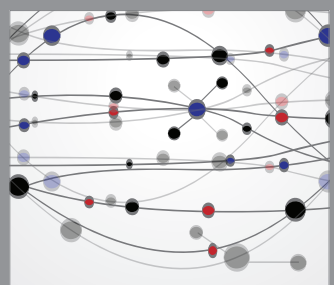

The Scientific World Journal
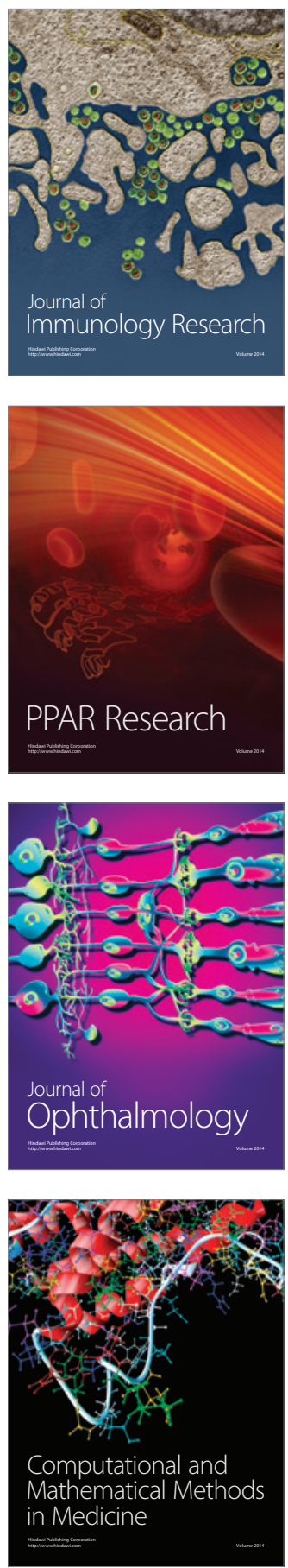

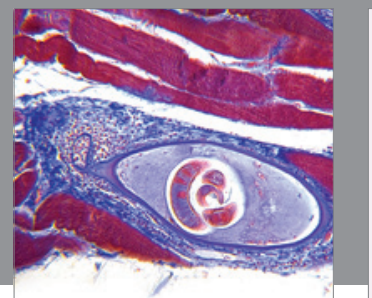

Gastroenterology

Research and Practice
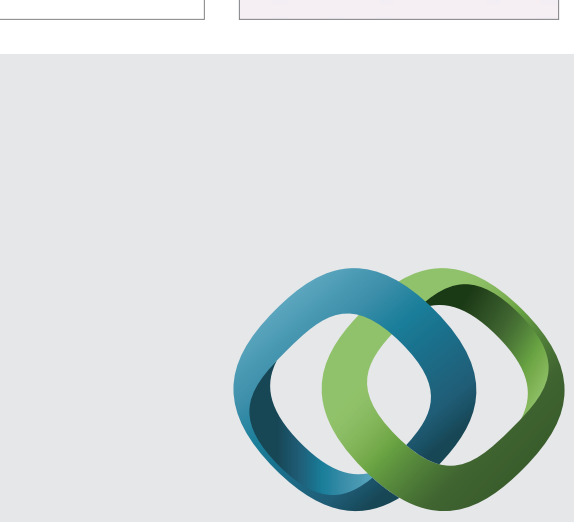

\section{Hindawi}

Submit your manuscripts at

http://www.hindawi.com
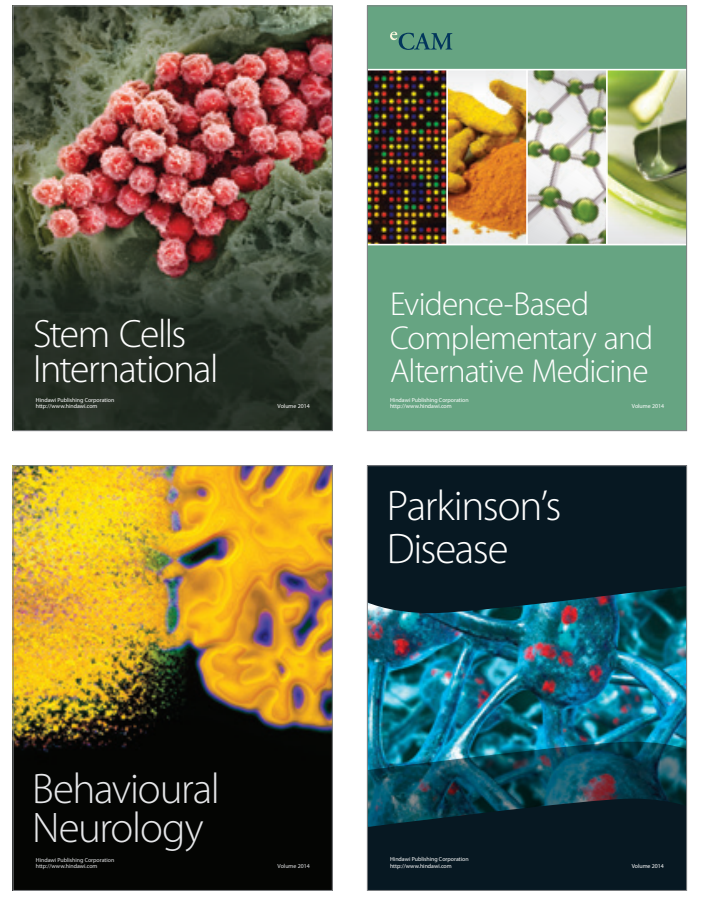
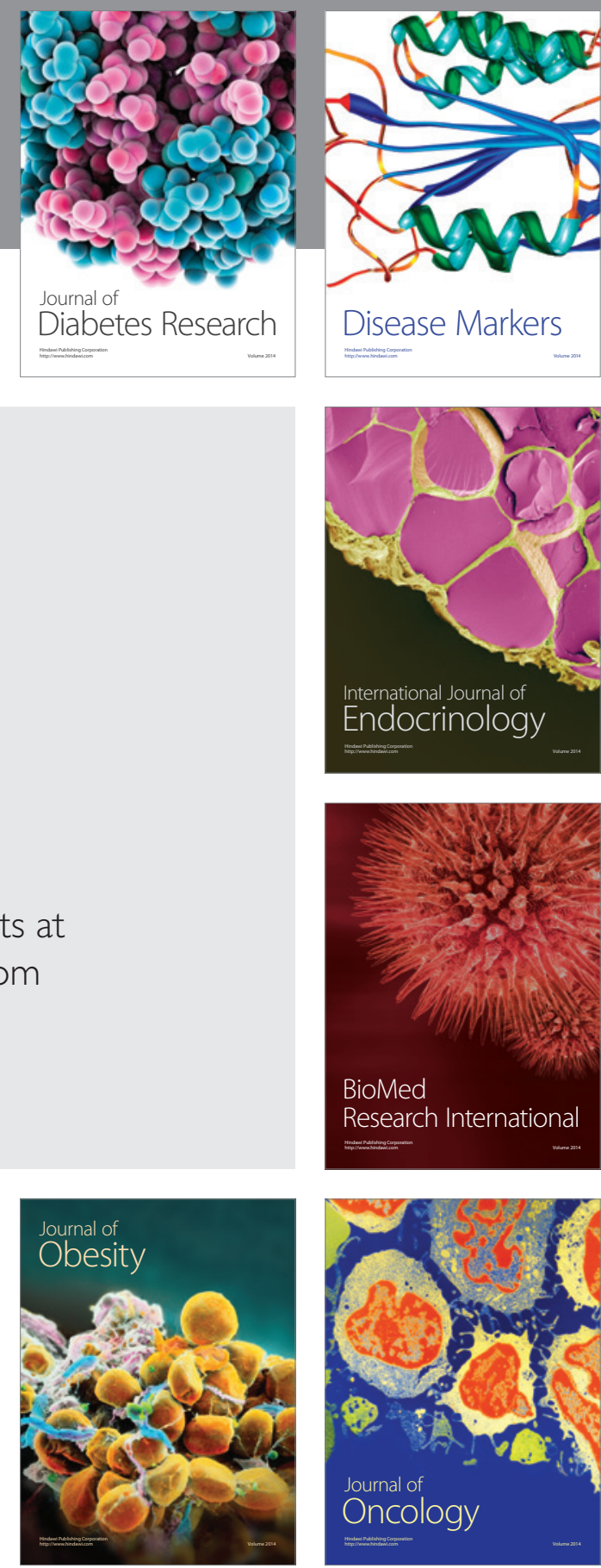

Disease Markers
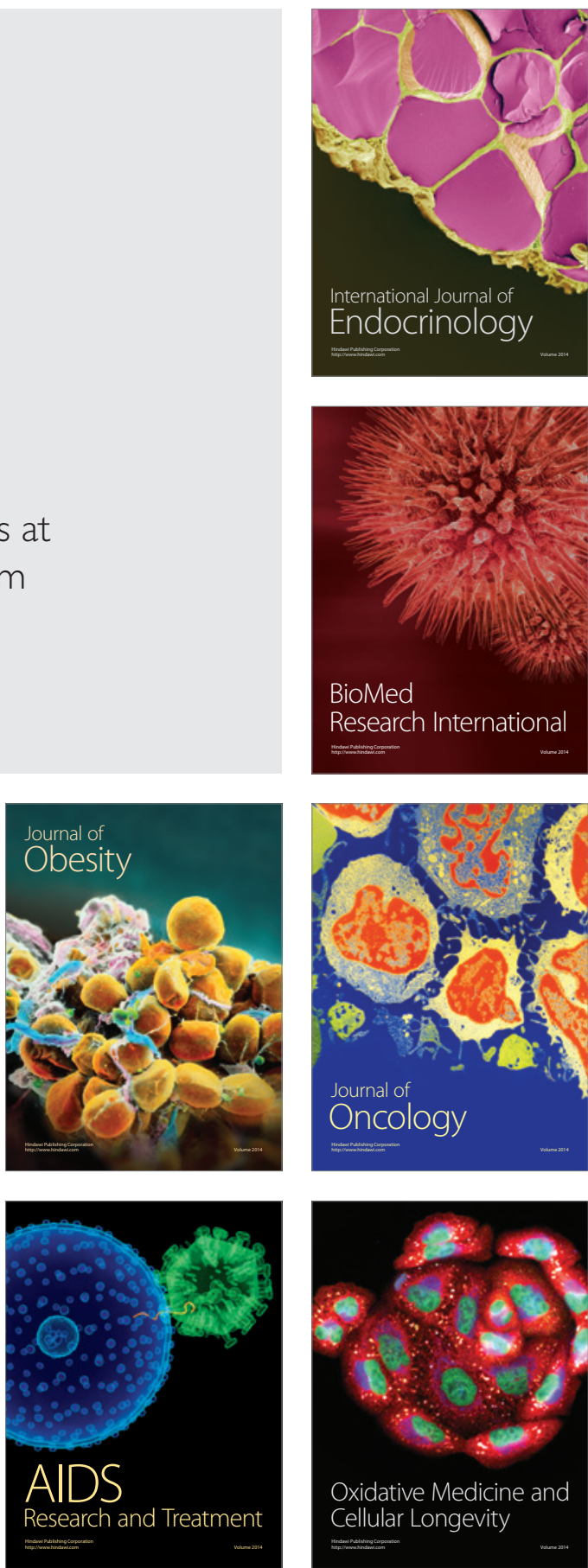